Original Research Paper

\title{
Keanekaragaman dan Kelimpahan Bivalvia di Perairan Pantai Waemulang Kabupaten Buru Selatan
}

\author{
Efraim Samson ${ }^{1}$ dan Daniati Kasale ${ }^{2}$ \\ 1,2 Jurusan Biologi, Fakultas Matematika dan Ilmu Pengetahuan Alam, Universitas Pattimura, Ambon, Indonesia
}

\section{Riwayat artikel}

Received : 4 Februari 2020

Revised : 17 Februari 2020

Accepted : 24 Februari 2020

Published : 27 Februari 2020

*Corresponding Author:

Efraim Samson,

Jurusan Biologi, FMIPA

UNPATTI, Ambon, Indonesia;

Email:

samsonefraim43@gmail.com
Abstrak: Bivalvia merupakan anggota kelas moluska yang memiliki nilai ekonomis dan menjadikannya sering dieksploitasi berlebih oleh masyarakat. Penelitian ini bertujuan untuk mengetahui indeks keanekaragaman dan kelimpahan bivalvia di Perairan Pantai Waemulang Kabupaten Buru Selatan. Pengambilan sampel dilakukan pada kondisi air surut dengan menggunakan metode transek linear kuadrat yang disesuaikan dengan luas area Perairan Pantai Waemulang, panjang garis pantai dan relif pantai. Disamping itu, dilakukan pula pengukuran parameter fisik kimia lingkungan sebagai data pendukung. Hasil penelitian menunjukkan bahwa bivalvia yang ditemukan terdiri dari 5 Ordo, 5 Family, 6 Genus, dan 7 Spesies, yakni Anadara antiquata, Gafrarium dispar, Modiolus modiolus, Fragum unedo, Pinna bicolor, Anadara granosa, dan Tapes literatus. Nilai kelimpahan tertinggi terdapat pada spesies Anadara antiquata, yakni 5.495 dan kelimpahan relatifnya $16.22 \%$. Sedangkan nilai kelimpahan terrendah terdapat pada spesies Tapes literatus, yakni 4.272, dan kelimpahan relatifnya $12.61 \%$. Nilai indeks keanekaragaman, yakni 1.93 atau termasuk kategori sedang dan indeks dominansi sebesar 0.14 yang menunjukkan tidak ada dominansi spesies. Hasil pengukuran parameter fisik kimia pun masih berada dalam kisaran optimal sesuai dengan standar baku mutu air laut untuk biota laut. Guna pemanfaatan dan pengelolaan bivalvia secara berkelanjutan di Perairan Pantai Waemulang Kabupaten Buru Selatan maka diperlukan penelitian sejenis secara berkala.

Kata Kunci: Bivalvia, Keanekaragaman, Kelimpahan, Waemulang.

Abstract: Bivalves is a member of the mollusk class with economic value and makes it often over exploited by the community. This study aims to determine the diversity index and abundance of bivalves in the Waemulang Coastal Waters of South Buru Regency. Sampling is done at low tide conditions using the linear quadratic transect method that is adjusted to the area of Waemulang Coastal Waters, coastline length and coastline. Besides that, physical chemical parameters were also measured as supporting data. The results showed that bivalves were found to consist of 5 Orders, 5 Families, 6 Genera, and 7 Species, namely Anadara antiquata, Gafrarium dispar, Modiolus modiolus, Fragum unedo, Pinna bicolor, Anadara granosa, and Tapes literatus. The highest abundance was found in Anadara antiquata, which was 5,495 and its relative abundance was $16.22 \%$. While the lowest abundance was found in Tapes literatus, which was 4.272 , and the relative abundance was $12.61 \%$. Diversity index value is 1.93 or including a medium category and dominance index of 0.14 which shows no species dominance. The results of the measurement of physical chemical parameters are still in the optimal range in accordance with sea water quality standards for marine biota. For the sustainable use and management of bivalves in the Waemulang Coastal Waters, South Buru Regency, regular research is needed.

Keywords: Bivalves, Diversity, Abundance, Waemulang.

\section{Pendahuluan}

Indonesia adalah Negara dengan posisi geografis yang sangat strategis. Diapit oleh dua samudera dan dua benua yang memungkinkan terjadinya pertukaran massa air, sehingga menjadikan perairan Indonesia kaya akan berbagai jenis organisme laut. Padang lamun merupakan salah satu ekosistem di perairan laut dangkalyang produktif dan sangat bermanfaat, terutama sebagai sumber kehidupan bagi organisme laut disekitarnya. 
Beberapa kelompok diantaranya seperti meiofauna, moluska, echinodermata, krustacea dan berbagai jenis ikan. sering ditemukan berasosiasi dengan lamun (Rochmady, 2010). Hal ini dikarenakan organismeorganisme laut tersebutmenjadikan area padang lamun sebagai tempat untuk tumbuh dan menetap, mencari makan, memijah, serta berlindung dari predator (Pratiwi, 2010; Rappe, 2010; Hermala et al., 2015).

Salah satu anggota dalam kelas moluska yang sering ditemukan pada area padang lamun adalah bivalvia. Adanya keterkaitan dalam siklus makanan dan karakteristik tipe substrat yang sama sebagai habitat, diduga menjadi faktor penyebab adanya hubungan yang erat antara lamun dan bivalvia. Serasah lamun yang mengendap didasar perairan akan diuraikan oleh mikroorganisme yang kemudian akan menjadi makanan bagi bivalvia (Insafitri, 2010).

Bivalvia merupakan salah satu jenis hewan laut yang memiliki nilai ekonomis. Beberapa jenis diantaranya dapat dijadikan sebagai bahan makanan, karena rasanya yang enak dan berprotein tinggi. Selain itu, adapula yang dijadikan sebagai bahan ornamen (hiasan). Menurut Sulistijo et al., (1980) dalam Supratman et al., (2019) sebagian besar dari antara 20 jenis moluska yang bernilai ekonomis yang ditemukan di Indonesia, termasuk ke dalam kelas bivalvia dan oleh karena nilai ekonomisnya sehingga sering terjadi eksploitasi yang berlebihan terhadap bivalvia yang bisa berdampak terhadap keanekaragaman dan kelimpahannya di alam. Keanekaragaman dan kelimpahan bivalvia di alam, dapat dipengaruhi oleh beberapa faktor, yaitu ketersediaaan makanan, kondisi lingkungan perairan (fisik kimia), kompetisi, adanya pemangsaan dari predator, serta tekanan dan perubahan lingkungan perairan oleh karena aktivitas manusia (Susiana, 2011; Budi et al., 2013).

Masyarakat Desa Waemulang, Kabupaten Buru Selatan, Maluku, umumnya sejak dulu telah memanfaatkan bivalvia (kerang-kerangan) sebagai bahan makanan. Adanya pemanfaatan bivalvia sebagai bahan makanan, tentunya akan mendorong aktivitas pengambilan dari lingkungan tempat hidupnya. Jika aktivitas pengambilan bivalvia tanpa memperhatikan kelestariannya, maka tentu hal tersebut dikhawatirkan dapat berdampak buruk bagi keberadaan (kelestarian) populasi Bivalvia.

Hasil penelitian Rukanah, (2019) dijelaskan bahwa salah satu faktor penyebab rendahnya indeks keanekaragaman bivalvia pada beberapa stasiun pengamatan, yakni adanya aktivitas manusia yang melakukan penangkapan tiap hari, sehingga menyebabkan perubahan populasi bivalvia (kerang). Kemudian, hasil penelitian Yuniarti, (2012) pun dijelaskan bahwa selain faktor karakteristik habitat, adanya aktivitas manusia juga turut berpengaruh terhadap perbedaan jumlah bivalvia yang ditemukan pada beberapa stasiun pengamatan, dengan nilai signifikan $(\mathrm{P}<0.05)$. Sama halnya pula dengan hasil penelitian Akhrianti et al., (2014) yang juga dijelaskan bahwa adanya eksploitasi oleh masyarakat setempat terhadap bivalvia yang memiliki nilai ekonomis tinggi dalam jumlah yang banyak serta intensitas yang tak terkendalikan, menyebabkan kurangnya jumlah spesies dan jumlah individu tiap spesies yang ditemukan pada masing-masing stasiun penelitian di pesisir Perairan Kecamatan Simpang Pesak Kabupaten Belitung Timur

Mengingat pentingnya organisme ini sebagai salah satu sumber daya yang sering dimanfaatkan oleh masyarakat Waemulang untuk dikonsumsi serta minimnya data hasil penelitian tentang keanekaragaman dan kelimpahan bivalvia di Perairan Pantai Waemulang, Kabupaten Buru Selatan, maka penelitian ini perlu untuk dilakukan agar dapat diperoleh data terkait status bivalvia yang meliputi jumlah spesies dan jumlah individu tiap spesies, tingkat keanekaragaman dan kelimpahan serta kondisi perairannya. Melalui data tersebut diharapkan dapat menjadi informasi ilmiah bagi penelitian selanjutnya dibidang terkait serta menjadi pertimbangan sekaligus langkah preventif dalam pemanfaatan dan pengelolaan bivalvia secara berkelanjutan di Perairan Pantai Waemulang, Kabupaten Buru Selatan.

\section{Metode Penelitian}

\section{Tipe dan Lokasi Penelitian}

Penelitian ini merupakan penelitian deskriptif kuantitatif dan bersifat observasional yang telah dilakukan di Perairan Pantai Waemulang Kecamatan Leksula Kabupaten Buru Selatan, Maluku.

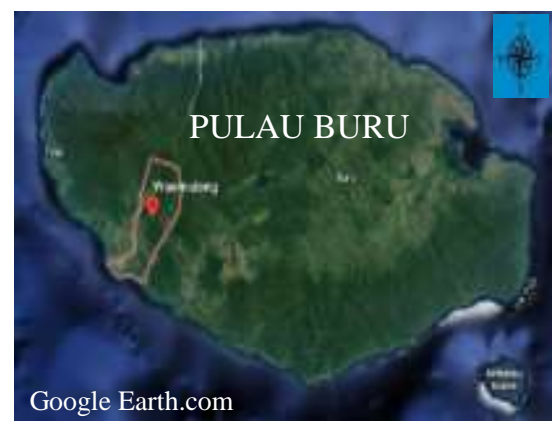

Gambar 1. Peta Lokasi Penelitian

\section{Prosedur Kerja}

Proses penelitian ini diawali dengan survei lokasi penelitian. Kemudian, dilanjutkan dengan penentuan area pengambilan sampel penelitian. Pengambilan sampel penelitian dilakukan pada kondisi air surut dengan menggunakan metode transek linear kuadrat yang disesuaikan dengan luas area Pantai Waemulang, panjang 
garis pantai dan relif pantai. Pada area pengambilan sampel penelitian yang telah ditentukan, diletakan 13 buah garis transek secara tegak lurus garis pantai, mulai dari pasang tertinggi hingga surut terendah, dengan jarak antara transek $25 \mathrm{~m}$. Pada tiap transek diletakan plot pengamatan bervariasi sebanyak 10-12 plot (sesuai relif pantai) yang diletakan secara selang-seling dengan ukuran $1 \mathrm{~m}$ x $1 \mathrm{~m}$ dan jarak antar plot pengamatan $10 \mathrm{~m}$.

Bivalvia yang ditemukan pada setiap plot pengamatan, dihitung jumlah spesies dan individu tiap spesies. Untuk keperluan identifikasi, maka diperlu dilakukan pengambilan beberapa individu dari masingmasing spesies bivalvia (1-3 individu) yang ditemukan. Terkhusus untuk bivalvia yang membenamkan diri di dalam substrat, maka perlu dilakukan penggalian substrat untuk proses pengambilannya. Sampel bivalvia yang diambil untuk proses identifikasi, dibersihkan terlebih dahulu dari lumpur atau kotoran yang menempel, setelah itu dimasukkan ke dalam kantong plastik bening yang telah diberi label sesuai setiap titik plotnya dan diawetkan dengan menggunakkan alkohol 70\%. Proses identifikasi dilakukan pada Laboratorium Pusat Penelitian Laut Dalam-LIPI Ambon, berdasarkan karakter morfologi spesies dan disesuaikan dengan referensi (Dharma 1992, 2005). Sebagai data pendukung, maka dilakukan pula pengukuran faktor fisik kimia lingkungan Perairan Pantai Waemulang Kabupaten Buru Selatan, yang meliputi suhu, $\mathrm{pH}$, Salinitas, dan DO, yang dilakukan pada saat air pasang.

\section{Analisis Data}

Data jumlah spesies dan jumlah individu tiap spesies bivalvia yang ditemukan, dianalisis dengan menggunakan rumus:

a) Kelimpahan (Odum, 1993 dalam Adli et al., 2016)

$$
\mathbf{D i}=\frac{\mathbf{n i}}{\mathbf{A}}
$$

Keterangan:

Di $=$ Kelimpahan jenis $i$

ni $=$ Jumlah total setiap individu dari jenis $i$

$\mathrm{A}=$ Luas total plot pengamatan $\left(\mathrm{m}^{2}\right)$

b) Kelimpahan Relatif (Odum, 1993 dalam Adli et al., 2016)

erangan:

$$
\mathrm{RDi}=\frac{\mathrm{ni}}{\sum \mathrm{n}} \times 100 \%
$$

$\mathrm{RDi}=$ Kepadatan relatif

ni $=$ Jumlah total spesies $i$

$\sum \mathrm{n}=$ Jumlah total individu seluruh spesies c) Indeks Keanekaragaman, Shannon-Wienner (Krebs, 1989 dalam Patty \& Rifai, 2013)

$$
H^{\prime}=\sum_{i=1}^{n} P i \ln P i
$$

Keterangan:

$\mathrm{H}^{\prime}=$ Indeks keanekaragaman

$\mathrm{Pi}=\sum$ ni/N (jumlah individu suatu spesies / jumlah total individu seluruh spesies)

ni $=$ Jumlah individu dari suatu jenis ke- $i$

$\mathrm{N}=$ Jumlah total individu seluruh jenis

Kriteria nilai indeks keanekaragaman, ShannonWiener $\left(\mathrm{H}^{\prime}\right)$ adalah sebagai berikut:

$\mathrm{H}^{\prime}<1=$ Keanekaragaman rendah

$1 \leq \mathrm{H}^{\prime} \leq 3=$ Keanekaragaman sedang

$\mathrm{H}^{\prime}>3=$ Keanekaragaman tinggi

d) Indeks Dominansi, Simpson (Krebs, 1989 dalam Patty \& Rifai, 2013)

$$
\mathbf{D}=\sum(\mathbf{P i})^{2}
$$

Keterangan:

$\mathrm{D}=$ Indeks Dominansi

$\mathrm{Pi}=$ Proporsi jumlah ke- $i$ terhadap jumlah total (ni/N)

Nilai indeks dominansi berkisar antara 0 - 1. Kategori dominansi didasarkan pada kriteria nilai indeks dominansi Simpson (C), yakni sebagai berikut:

$$
\begin{aligned}
& 0.00<\mathrm{C} \leq 0.50=\text { Kategori rendah } \\
& 0.50<\mathrm{C} \leq 1.00=\text { Kategori tinggi }
\end{aligned}
$$

\section{Hasil dan Pembahasan}

\section{Komposisi Jenis dan Kelimpahan Jenis Bivalvia}

Dari hasil penelitian ini, spesies bivalvia yang ditemukan di Perairan Pantai Waemulang Kabupaten Buru Selatan, yakni sebanyak 7 spesies dari 5 Ordo, 5 Family, dan 6 Genus. (Gambar 2). Dari ketujuh spesies bivalvia yang ditemukan, jumlah individu tertinggi hingga terendah secara berurutan (Tabel 1), yakni Anadara antiquata (808 Ind/ $\left.\mathrm{m}^{2}\right)$, Gafrarium dispar $(753$ $\left.\mathrm{Ind} / \mathrm{m}^{2}\right)$, Modiolus modiolus $\left(732 \mathrm{Ind} / \mathrm{m}^{2}\right)$, Fragum unedo (710 Ind $\left./ \mathrm{m}^{2}\right)$, Pinna bicolor (686 Ind $\left./ \mathrm{m}^{2}\right)$, Anadara granosa $\left(662 \mathrm{Ind} / \mathrm{m}^{2}\right)$, dan Tapes literatus $\left(628 \mathrm{Ind} / \mathrm{m}^{2}\right)$. 


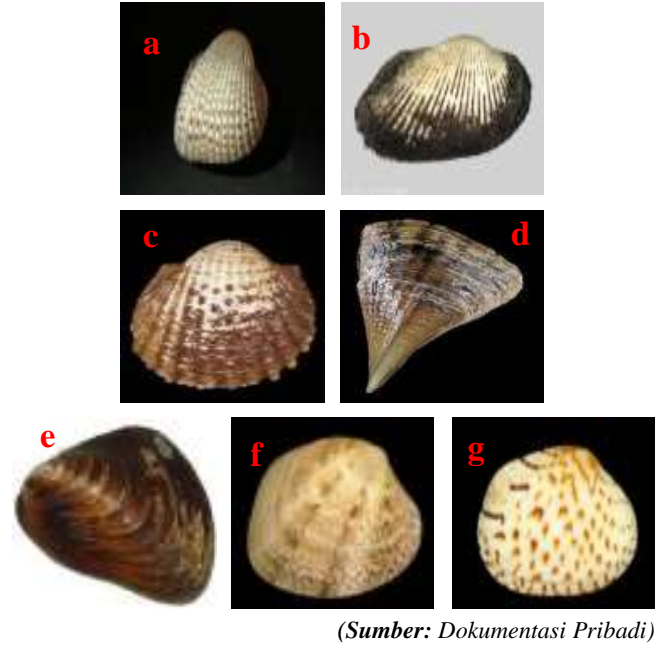

Gambar 2. Jenis-Jenis Bivalvia di Perairan Pantai Waemulang Kabupaten Buru Selatan

Keterangan: a). Fragum unedo; b). Anadara antiquata;

c). Anadara granosa; d). Pinna bicolor

e). Modiolus modiolus; f). Tapes literatus;

g). Gafrarium dispar

Kemudian, dari hasil perhitungan kelimpahan jenis berdasarkan data jumlah spesies dan jumlah individu tiap spesies bivalvia yang diperoleh, maka spesies bivalvia dengan nilai kelimpahan jenis dan kelimpahan relatif tertinggi hingga terendah secara berurutan, yakni Anadara antiquata, Gafrarium dispar, Modiolus modiolus, Fragum unedo, Pinna bicolor, Anadara granosa, dan Tapes literatus (Tabel 1 \& 2).
Tabel 1. Kelimpahan Jenis Bivalvia di Perairan Pantai Waemulang Kabupaten Buru Selatan

\begin{tabular}{|c|l|c|c|c|}
\hline \multirow{2}{*}{ No. } & \multicolumn{1}{|c|}{ Spesies } & \multicolumn{3}{|c|}{ Seluruh Transek } \\
\cline { 3 - 5 } & $\begin{array}{c}\mathbf{n i} \\
\left(\mathbf{I n d} / \mathbf{m}^{\mathbf{2}}\right)\end{array}$ & $\mathbf{K i}$ & $\begin{array}{c}\mathbf{K r} \\
(\boldsymbol{\%})\end{array}$ \\
\hline 1 & Fragum unedo & 710 & 4.829 & 14.25 \\
\hline 2 & $\begin{array}{l}\text { Anadara } \\
\text { antiquata }\end{array}$ & 808 & 5.495 & 16.22 \\
\hline 3 & $\begin{array}{l}\text { Anadara } \\
\text { granosa }\end{array}$ & 662 & 4.503 & 13.29 \\
\hline 4 & Pinna bicolor & 686 & 4.666 & 13.77 \\
\hline 5 & $\begin{array}{l}\text { Modiolus } \\
\text { modiolus }\end{array}$ & 732 & 4.979 & 14.70 \\
\hline 6 & Tapes literatus & 628 & 4.272 & 12.61 \\
\hline 7 & $\begin{array}{l}\text { Gafrarium } \\
\text { dispar }\end{array}$ & 753 & 5.122 & 15.12 \\
\hline & Jumlah & $\mathbf{4 9 7 9}$ & $\mathbf{3 3 . 8 6 7}$ & $\mathbf{9 9 . 9 6}$ \\
\hline
\end{tabular}

Keterangan: ni (Jumlah Individu Spesies); Ki (Kelimpahan Jenis); $\mathrm{Kr}$ (Kelimpahan Relatif)

Berdasarkan data hasil pada Tabel 1 dan 2, maka terlihat bahwa diantara ketujuh spesies bivalvia yang ditemukan pada Perairan Pantai Waemulang Kabupaten Buru Selatan, Anadara antiquata adalah spesies dengan jumlah individu serta kelimpahan tertinggi, sedangkan yang terendah, yakni spesies Tapes literatus. Tingginya jumlah individu dan kelimpahan spesies Anadara antiquata, bila dibandingkan dengan spesies lainnya, diduga karena spesies ini mampu beradaptasi dengan kondisi habitatnya pada Perairan Pantai Waemulang yang didominasi oleh substrat pasir berlumpur dan ditumbuhi lamun.

Tabel 2. Taksa Bivalvia di Perairan Pantai Waemulang Kabupaten Buru Selatan

\begin{tabular}{|c|c|c|c|c|c|}
\hline Class & Ordo & Family & Genus & Spesies & $\begin{array}{l}\text { Jumlah } \\
\text { (Ind/m²) }\end{array}$ \\
\hline \multirow{7}{*}{ Bivalvia } & Veneroida & Cardiidae & Fragum & Fragum unedo & 710 \\
\hline & \multirow{2}{*}{ Arcoidea } & \multirow{2}{*}{ Arcidae } & \multirow{2}{*}{ Anadara } & Anadara antiquata & 808 \\
\hline & & & & Anadara granosa & 662 \\
\hline & Ostreida & Pinnidae & Pinna & Pinna bicolor & 686 \\
\hline & Mytilida & Mytilidae & Modiolus & Modiolus modiolus & 732 \\
\hline & \multirow{2}{*}{ Venerida } & \multirow{2}{*}{ Veneridae } & Tapes & Tapes literatus & 628 \\
\hline & & & Gafrarium & Gafrarium dispar & 753 \\
\hline \multicolumn{5}{|c|}{ Jumlah Total Individu Spesies Bivalvia } & 4979 \\
\hline
\end{tabular}

Substrat dasar Perairan Pantai Waemulang dengan karakter pasir berlumpur, diduga mampu mendukung kehidupan spesies Anadara antiquata. Spesies ini lebih menyukai habitat pasir berlumpur untuk memperoleh makanan (filter feeder) dan kawin. Ketika tiba masa kawinnya, maka spesies ini akan bermigrasi ke daerah yang bersubstrat lumpur dan ditumbuhi tumbuhan laut agar telur-telur yang dilepaskan terhindar dari predator hingga menetas sendiri. Juvenil Anadara antiquata akan tumbuh menjadi populasi yang pesat bila mendapatkan makanan yang melimpah di sekitar daerah bersubstrat dan 
berlumpur (Hidayat, 2011; Dayanti et al., 2017; Aprillia \& Sudibyo, 2019).

Hasil penelitian Nurdin et al., (2006) menyatakan bahwa lapisan pasir berlumpur yang tebal dan luas pada lokasi penelitian, menyebabkan spesies Anadara antiquata cocok hidup pada substrat tersebut dan memiliki tingkat kepadatan tertinggi pada ketiga stasiun penelitian. Hal ini didukung pula oleh Mubarak, (1987) dalam Komala, (2012) yang menyatakan bahwa spesies Anadara antiquata lebih menyukai area dasar perairan dengan jumlah pasir yang lebih banyak. Tidak hanya dapat hidup di dasar perairan dengan substrat pasir berlumpur, Anadara antiquata juga dapat ditemukan pada ekosistem estuari, mangrove dan padang lamun (Komala, 2012). Kemudian, Akhrianti et al., (2014) dalam hasil penelitiannnya pun menyatakan bahwa genus Anadara banyak tersebar di wilayah Indo-Pasifik khususnya pada substrat dasar berlumpur, dan pasir berlumpur. Begitu pula dengan hasil penelitian Lailiyah et al., (2016) yang juga menyatakan bahwa beberapa spesies dari kelas bivalvia, seperti spesies Anadara granosa, dan Andara antiquata, hanya ditemukan pada substrat pasir berlumpur. Hal ini diduga karena substrat pasir berlumpur banyak mengandung bahan organic.

Selanjutnya, untuk spesies Tapes literatus, rendahnya jumlah individu dan kelimpahan spesies tersebut diduga karena spesies ini memiliki kemampuan menyebar yang sempit serta kondisi habitat yang kurang sesuai dengan kehidupan kerang tersebut. Menurut Kinasih, (2018) spesies Tapes literatus biasanya ditemukan di area dekat bakau dengan substrat berpasir hingga berlumpur. Sedangkan pada lokasi penelitian ini, lebih didominan oleh lamun.

\section{Indeks Keanekaragaman dan Dominansi}

Berdasarkan hasil perhitungan indeks keanekaragaman maka nilai indeks keanekaragaman spesies bivalvia di Perairan Pantai Waemulang Kabupaten Buru Selatan, yakni 1.93 (Tabel 3). Sesuai dengan kriteria nilai indeks keanekaragaman, Shannon-Wiener (Krebs, 1989 dalam Patty \& Rifai, 2013), jika H' < 1 maka tingkat keanekaragaman rendah. Kemudian, jika $1 \leq \mathrm{H}^{\prime} \leq 3$ maka tingkat keanekaragaman sedang., dan jika $\mathrm{H}^{\prime}>3$ maka tingkat keanekaragaman tinggi. Dengan demikian, nilai indeks keanekaragaman spesies bivalvia di Perairan Pantai Waemulang Kabupaten Buru Selatan, termasuk dalam kategori sedang.

Indeks keanekaragaman dapat digunakan untuk mengetahui kestabilan suatu komunitas. Disamping itu, terdapat beberapa faktor yang turut mempengaruhi tinggi rendahnya nilai keanekaragaman spesies antara lain, jumlah spesies yang ditemukan, adanya individu suatu spesies yang ditemukan melebihi jumlah individu spesies lainnya, kondisi substrat dan ekosistem sebagai habitat dari spesies yang ditemukan (Daget, 1976 dalam Andra, 2014; Hermala et al., 2015). Sedangkan menurut Odum, (1993) dan Clark, (1974) dalam Kisman et al., (2016), keanekaragaman spesies tidak hanya ditentukan oleh banyaknya spesies yang ditemukan, tetapi juga karena sifat komunitas yang ditentukan oleh banyaknya variasi spesies, kestabilan habitat serta kemerataan dan kelimpahan individu tiap spesies pada suatu komunitas. Oleh karena itu, jika kondisi suatu habitat semakin baik atau stabil maka akan lebih banyak variasi spesies dan kekayaan biota yang hidup di dalamnya.

Hasil perhitungan indeks keanekaragaman spesies bivalvia sekaligus memberikan gambaran, bahwa keanekaragaman spesies bivalvia di Perairan Pantai Waemulang masih tergolong cukup baik. Nilai indeks keanekaragaman sedang, mengindikasikan bahwa Perairan Pantai Waemulang berada dalam kondisi cukup stabil dan interaksi spesies yang terjadi di dalam komunitas cukup baik. Selain itu, indeks keanekaragaman sedang juga mengindikasikan bahwa Perairan Pantai Waemulang produktivitasnya cukup baik, kondisi ekosistem cukup seimbang, dan tekanan ekologi sedang sehingga masih layak bagi kehidupan bivalvia. Menurut Odum, (1994) dalam Kisman et al., (2016) nilai indeks keanekaragaman dengan kategori sedang, menunjukkan bahwa kondisi lingkungan perairan tersebut masih dapat ditolerir oleh bivalvia serta masih bisa mendukung keberhasilan hidup dan reproduksi bivalvia

Hasil serupa juga ditunjukkan oleh hasil penelitian Hermala et al., (2015), yang mana melalui 30 titik atau plot pengamatan di pesisir pantai Dolpin Teluk Bakau Kabupaten Bintan, ditemukan 7 spesies bivalvia dengan jumlah total individu 155 dan nilai indeks keanekaragaman jenis sebesar 2,6 atau termasuk kategori sedang. Kemudian, oleh Supratman et al., (2019) pada perairan Pulau Semujur Kepulauan Bangka Belitung, diperoleh 8 spesies bivalvia dengan nilai kepadatan berkisar antara $8,4 \mathrm{ind} / \mathrm{m}^{2}$ s.d $21.2 \mathrm{ind} / \mathrm{m}^{2}$ dan nilai indeks keanekaragaman bivalvia berkisar antara $1.54 \mathrm{s.d}$ 2.184 atau termasuk dalam kategori sedang. Begitu pula dengan hasil penelitian Kisman et al., (2016) pada perairan laut pulau Maputi, ditemukan sebanyak 14 spesies bivalvia dengan nilai indeks keanekaragaman sebesar 1.05 atau termasuk pula dalam kategori sedang.

Selanjutnya, berdasarkan hasil perhitungan nilai indeks dominansi (C) maka nilai indeks dominansi spesies bivalvia di Perairan Pantai Waemulang Kabupaten Buru Selatan, yakni 0.14 (Tabel 3). Sesuai dengan indeks kategori indeks dominansi Simpson (Krebs, 1989 dalam Patty \& Rifai, 2013), maka nilai tersebut termasuk dalam kategori rendah. Nilai indeks dominansi rendah menunjukkan, bahwa pada lokasi tersebut tidak ada spesies bivalvia yang mendominasi. Hasil ini lebih menegaskan lagi bahwa kondisi lingkungan di perairan Pantai Waemulang cukup stabil dan kualitas 
lingkungannya sangat mendukung kelangsungan hidup semua jenis bivalvia yang ada sehingga memungkinkan interaksi spesies yang terjadi di dalam komunitas cukup baik.

Tabel 3. Indeks Keanekaragaman dan Dominansi Bivalvia di Perairan Pantai Waemulang Kabupaten Buru Selatan

\begin{tabular}{|c|c|c|c|c|c|c|c|c|}
\hline No. & Nama Spesies & ni & $\mathbf{P i}$ & $\mathbf{P i}^{2}$ & $\ln \mathbf{P i}$ & $\mathbf{P i} \ln \mathbf{P i}$ & $\mathbf{H}^{\prime}$ & $\mathbf{C}$ \\
\hline 1 & Fragum unedo & 710 & 0.142 & 0.020 & -1.951 & 0.277 & \multirow{7}{*}{1.93} & \multirow{7}{*}{0.14} \\
\hline 2 & Anadara antiquata & 808 & 0.162 & 0.026 & -1.820 & 0.294 & & \\
\hline 3 & Anadara granosa & 662 & 0.132 & 0.017 & -2.024 & 0.267 & & \\
\hline 4 & Pinna bicolor & 686 & 0.137 & 0.018 & -1.987 & 0.272 & & \\
\hline 5 & Modiolus modiolus & 732 & 0.147 & 0.021 & -1.917 & 0.281 & & \\
\hline 6 & Tapes literatus & 628 & 0.126 & 0.015 & -2.071 & 0.261 & & \\
\hline 7 & Gasfrarium dispar & 753 & 0.151 & 0.022 & -1.890 & 0.285 & & \\
\hline \multicolumn{2}{|r|}{ Jumlah } & 4979 & & 0.142 & & 1.939 & & \\
\hline
\end{tabular}

\section{Parameter Fisik Kimia}

Hasil pengukuran parameter fisik kimia di Perairan Pantai Waemulang Kabupaten Buru Selatan menunjukan, bahwa suhu berkisar antara $29.4-32{ }^{\circ} \mathrm{C}$, Salinitas 30 $32 \%$, pH 6.19-7.09, dan DO 4.7 - 6.9 mg/l. Sedangkan menurut standar baku mutu air laut (Kepmen LH No. 51 Tahun 2004), kisaran suhu optimal untuk pertumbuhan biota laut, yakni dinyatakan secara alami; kisaran salinitas optimal, yakni dinyatakan secara alami; kisaran $\mathrm{pH}$ optimal, yakni 7 - 8.5; dan kisaran DO optimal, yakni >5 (mg/l). Hasil pengukuran parameter fisik kimia di Perairan Pantai Waemulang Buru Selatan tersaji pada Tabel 4.

Tabel 4. Parameter Fisik Kimia di Perairan Pantai Waemulang Buru Selatan

\begin{tabular}{|c|c|c|c|}
\hline No. & $\begin{array}{c}\text { Parameter } \\
\text { Fisik Kimia }\end{array}$ & Kisaran & $\begin{array}{l}\text { Standar Baku } \\
\text { Mutu Air Laut } \\
\text { untuk Biota Laut } \\
\text { Kepmen LH No. } \\
\text { 51 Tahun 2004) }\end{array}$ \\
\hline 1 & Suhu $\left({ }^{\circ} \mathrm{C}\right)$ & $29.4-32$ & Alami \\
\hline 2 & Salinitas $(\%)$ & $30-32$ & Alami \\
\hline 3 & $\mathrm{pH}$ & $6.19-7.09$ & $7-8.5$ \\
\hline 4 & DO $(\mathrm{mg} / \mathrm{l})$ & $4.7-6.9$ & $>5$ \\
\hline
\end{tabular}

Parameter fisik kimia perairan merupakan salah satu faktor yang turut berpengaruh terhadap tinggi rendahnya kelimpahan suatu organisme, sehingga kehadiran serta kelimpahan biota dalam suatu lingkungan perairan dapat menggambarkan kualitas perairan tersebut. Bila terjadi penurunan kualitas suatu perairan maka dapat berdampak langsung pada biota yang hidup di dalamnya. Bivalvia merupakan salah satu biota yang dapat terpengaruh langsung jika terjadi penurunan kualitas perairan sebab karakteristik hidupnya yang menetap atau sesil (Susiana, 2011; Budi et al., 2013; Rukanah, 2019). Namun, kisaran toleransi dan sensivitas terhadap perubahan lingkungan pada masing-masing spesies pun berbeda-beda. Keanekaragaman dan kelimpahannya pun sangat bergantung pada toleransi, aktivitas dan sensivitas terhadap perubahan lingkungan (Aininnur et al., 2015).

Berdasarkan data hasil pengukuran yang diperoleh, parameter fisik kimia perairan (suhu, salinitas, $\mathrm{pH}$, dan DO) di Perairan Pantai Waemulang bila dibandingkan dengan baku mutu air laut untuk biota laut yang ditetapkan oleh Menteri Negara Lingkungan Hidup (Kepmen LH No. 51 Tahun 2004), maka semua parameter tersebut masih berada dalam kisaran optimal dan toleran bagi kelangsungan hidup bivalvia. Dalam baku mutu air laut untuk biota laut, standar parameter suhu dinyatakan secara alami, yang artinya sesuai dengan kondisi normal suatu lingkungan, dan dapat bervariasi setiap saat tergantung kondisi siang atau malam, musim, serta diperbolehkan terjadi perubahan sampai dengan $<2{ }^{\circ} \mathrm{C}$ dari suhu alami. Begitu pula dengan standar parameter salinitas yang dinyatakan secara alami, yang artinya sesuai dengan kondisi normal suatu lingkungan, dan dapat bervariasi setiap saat tergantung kondisi siang atau malam, musim, serta diperbolehkan terjadi perubahan sampai dengan $<5 \%$ salinitas rata-rata musiman.

Suhu merupakan salah satu faktor lingkungan yang paling berpengaruh terhadap proses metabolisme, distribusi dan kelimpahan, pemijahan dan penetasan, serta aktivitas dan pertumbuhannya (Islami, 2013; Mardiani, 2014). Akan tetapi, bivalvia memiliki kemampuan untuk dapat bertahan hidup hingga kisaran suhu tertentu. Menurut hasil penelitian Litaay et al. (2014), suhu perairan $31-38^{\circ} \mathrm{C}$ masih bisa ditolerir oleh bivalvia. Hal ini diduga berkaitan dengan bentuk morfologi bivalvia yang secara umumnya memiliki cangkang sehingga menyebabkan bivalvia dapat bertahan hingga pada kisaran suhu tersebut. Selanjutnya Clark, (1974) dalam Rajab et al., (2016) juga menyatakan bahwa bivalvia sebagai salah satu organisme yang bersifat Sessile 
(menetap) cenderung memiliki toleransi terhadap suhu yang berkisar $30-40^{\circ} \mathrm{C}$. Hal ini terkait juga dengan morfologi cangkang yang tebal dan sifat membenamkan diri dalam substrat. Dengan demikian suhu yang terukur pada saat penelitian layak untuk kehidupan bivalvia karena masih berada dalam kisaran toleransi.

Salinitas juga merupakan salah satu faktor lingkungan yang turut berpengaruh terhadap kelangsungan hidup organisme laut, termasuk bivalvia. Bila terjadi fluktuasi salinitas pada perairan maka berpengaruh pula terhadap peningkatan rata-rata metabolismenya diatas tingkat normal (Marpaung, 2013; Kinasih, 2018). Sama halnya dengan suhu, bivalvia dewasa juga toleran terhadap kondisi salinitas. Bila kondisi eksternal kurang menguntungkan (tidak sesuai), maka bivalvia dewasa dapat menutup kedua cangkangnya bahkan dapat menghentikan produksi byssus-tiye untuk melindungi kondisi tubuhnya dari kondisi lingkungan tersebut (Islami, 2013).

Begitu pula dengan parameter $\mathrm{pH}$ dan DO. Menurut Odum, (1993) dalam Rajab et al., (2016), perairan dengan $\mathrm{pH} 6-9$ merupakan perairan dengan kesuburan tinggi dan tergolong produktif karena memiliki kisaran $\mathrm{pH}$ yang dapat mendorong pembongkaran bahan organik yang ada dalam perairan menjadi mineralmineral. Organisme perairan mempunyai kemampuan berbeda dalam mentoleransi $\mathrm{pH}$ perairan. Kematian lebih sering diakibatkan karena $\mathrm{pH}$ yang rendah daripada $\mathrm{pH}$ yang tinggi (Pescod, 1973 dalam Wijayanti, 2007). Nilai $\mathrm{pH}$ yang mendukung kehidupan Mollusca berkisar antara $5,7-8,4$, dan khusus untuk bivalvia batas kisaran $\mathrm{pH}$-nya 5,8 - 8,3 (Wijayanti, 2007).

\section{Kesimpulan}

Berdasarkan hasil penelitian yang diperoleh maka kesimpulan yang dapat diambil, yaitu bivalvia yang ditemukan di Perairan Pantai Waemulang Kabupaten Buru Selatan terdiri dari 5 Ordo, 5 Family, 6 Genus, dan 7 Spesies, yang meliputi Anadara antiquata $\left(808 \mathrm{Ind} / \mathrm{m}^{2}\right)$, Gafrarium dispar (753 Ind/ $\left.\mathrm{m}^{2}\right)$, Modiolus modiolus $(732$ $\left.\mathrm{Ind} / \mathrm{m}^{2}\right)$, Fragum unedo $\left(710 \mathrm{Ind} / \mathrm{m}^{2}\right)$, Pinna bicolor $(686$ $\left.\mathrm{Ind} / \mathrm{m}^{2}\right)$, Anadara granosa $\left(662 \mathrm{Ind} / \mathrm{m}^{2}\right)$, dan Tapes literatus $\left(628 \mathrm{Ind} / \mathrm{m}^{2}\right)$. Nilai kelimpahan tertinggi dimiliki oleh spesies Anadara antiquata, yakni sebesar 5.495, dengan kelimpahan relative sebesar $16.22 \%$. Sedangkan nilai kelimpahan terrendah dimiliki oleh spesies Tapes literatus, yakni sebesar 4.272, dengan kelimpahan relatif sebesar $12.61 \%$. Kemudian, hasil perhitungan indeks keanekaragaman bivalvia yakni 1,93 atau termasuk kategori sedang dan indeks dominansi 0.14, yang menunjukkan tidak ada dominansi spesies. Hasil pengukuran parameter fisik kimia pun masih berada dalam kisaran optimal dan toleran, sesuai dengan standar baku mutu air laut untuk biota laut.
Pentingnya bivalvia sebagai salah satu sumber daya yang sering dimanfaatkan oleh masyarakat Waemulang untuk dikonsumsi maka perlu dilakukan penelitian secara berkala yang dilengkapi dengan uji toksisitas pada bivalvia agar tetap terpantau status dan kondisi keberadaan bivalvia guna pemanfaatan dan pengelolaan bivalvia secara berkelanjutan di Perairan Pantai Waemulang, Kabupaten Buru Selatan.

\section{Ucapan Terima Kasih}

Penulis mengucapkan terima kasih untuk semua pihak, terkhusus kepada Pusat Penelitian Laut DalamLIPI Ambon atas seluruh dukungannya dalam penyelesaian penelitian ini.

\section{Daftar Pustaka}

Adli, A., Rizal, A. \& Ya'la, Z. R. (2016). Profil Ekosistem Lamun Sebagai Salah Satu Indikator Kesehatan Pesisir Perairan Sabang Tende Kabupaten Tolitoli. Jurnal Sains dan Teknologi Tadulako, 5(1), 49-62. http://jurnal.untad.ac.id/jurnal/index.php/JSTT/art icle/view/6960/5597.

Aininnur, A., Putro, S. P. \& Muhammad, F. (2015). Hubungan Faktor Fisika-Kimia Perairan Terhadap Kelimpahan Moluska di Area Keramba Jaring Apung Sistem Polikultur Teluk Awerange, Sulawesi Selatan. Jurnal Akademika Biologi, 4(4), 47-52. https://ejournal43.undip.ac.id/index.php/biologi/a rticle/view/19429/18428.

Akhrianti, I., Bengen, D. G. \& Setyobudiandi, I. (2014). Spatial Distribution and Habitat Preference of Bivalvia in The Coastal Waters of Simpang Pesak Sub District, East Belitung District. Jurnal ilmu dan teknologi kelautan tropis, 6(1), 171-185. doi: https://doi.org/10.29244/jitkt.v6i1

Andra, S. D., Zulfikar, A. \& Zen, L. W. (2014). Pola Sebaran dan Struktur Komunitas Pelecypoda di Perairan Ekosistem Padang Lamun Desa Teluk Bakau. (Skripsi), Program Studi Manajemen Sumberdaya Perairan, Fakultas Ilmu Kelautan dan Perikanan, Universitas Maritim Raja Ali Haji, Tanjung Pinang, Riau.

http://jurnal.umrah.ac.id/wpcontent/uploads/gravity_forms/1ec61c9cb232a03a96d0947c6478e525e/2014/06/d elly-andra-s.pdf.

Aprillia, P. A. \& Sudibyo, M. (2019). Analisis Asam Amino Non Esensial Pada Kerang Bulu (Anadara 
antiquata) Di Perairan Pantai Timur Sumatera Utara. Jurnal Biosains, 5(1), 23-30. doi: 10.24114/jbio.v5i1.12166

Budi, D. A., Suryono, C. A. \& Ario, R. (2013). Studi Kelimpahan Gastropoda di Bagian Timur Perairan Semarang Periode Maret-April 2012. Journal of Marine Research, 2(4), 56-65. doi: 10.14710/jmr.v2i4.3684

Dayanti, F., Bahtiar \& Ishak, E. (2017). Kepadatan dan Distribusi Kerang Bulu (Anadara antiquata L, 1758) Di Perairan Wangi-wangi Selatan Desa Numana Kabupaten Wakatobi. Jurnal Manajemen Sumber Daya Perairan, 2(2), 113-122. http://ojs.uho.ac.id/index.php/JMSP/article/view/ 2578/1923.

Dharma, B. (1992). Siput dan Kerang Indonesia. Indonesia Shells II. Verlag Christa Hemmen. Wiesbaden.

Dharma, B. (2005). Recent and Fossil. Indonesian Shells. Conchbook. Germany.

Hermala, Zulfikar, A. \& Raza'I, S. T. (2015). Hubungan Kerapatan Lamun Dengan Kelimpahan Bivalvia Dipesisir Pantai Dolpin Desa Teluk Bakau Kabupaten Bintan. (Skripsi), Program Studi Manajemen Sumberdaya Perairan, Fakultas Ilmu Kelautan dan Perikanan, Universitas Maritim Raja Ali Haji, Tanjungpinang, Kepulauan Riau. jurnal.umrah.ac.id/wpcontent/uploads/gravity_forms/1ec61c9cb232a03a96d0947c6478e525e/2015/09/ju rnal-hermala-msp.pdf.

Hidayat, T. (2011). Profil Asam Amino Kerang Bulu (Anadara antiquata). (Skripsi), Departemen Teknologi Hasil Perairan, Fakultas Perikanan dan Ilmu Kelautan, Institut Pertanian Bogor, Bogor. https://www.researchgate.net/publication/330702 274_profil_asam_amino_kerang_bulu_anadara_a ntiquata_taufik_hidayat.

Insafitri. (2010). Keanekaragaman, Keseragaman, dan Dominansi Bivalvia di Area Buangan Lumpur Lapindo Muara Sungai Porong. Jurnal Kelautan, 3(1), 54-59. doi: https://doi.org/10.21107/jk.v3i1

Islami, M. M. (2013). Pengaruh Suhu dan Salinitas Terhadap Bivalvia. Oseana, 38(2), 1-10. http://oseanografi.lipi.go.id/perpustakaan/reposito ry/showpdf/430.
Kinasih, A. G. (2018). Studi Hubungan Struktur Komunitas Dan Indeks Ekologi Makrobenthos Dengan Kualitas Perairan Di Rumah Mangrove Wonorejo, Surabaya. (Skripsi), Program Studi Ilmu Kelautan, Fakultas Sains dan Teknologi, Universitas Islam Negeri Sunan Ampel, Surabaya. http://digilib.uinsby.ac.id/27039/1/Aulia\%20Gust i\%20Kinasih_H74214011.pdf.

Kisman, D., Ramadhan, A. \& Djirimu, M. (2016). Jenisjenis dan Keanekaragaman Bivalvia di Perairan Laut Pulau Maputi Kecamatan Sojol Kabupaten Donggala dan Pemanfaatannya Sebagai Media Pembelajaran Biologi. e-Jurnal Ilmu Pendidikan Biologi, 4(1), 1-14. http://jurnal.untad.ac.id/jurnal/index.php/EBiol/ar ticle/view/7394/5918

Keputusan Menteri Negara Lingkungan Hidup (2004). No. 51 Tahun 2004 Tentang Baku Mutu Air Laut Untuk Biota Laut, 32 C.F.R. https://onlimo.bppt.go.id/Regulasi/km512004.htm ) .

Komala, R. (2012). Analisis Ekobiologi Sebagai Dasar Pengelolaan Sumberdaya Kerang Darah (A. granosa) di Teluk Lada Perairan Selat Sunda. (Tesis), Sekolah Pasca Sarjana, Institut Pertanian Bogor, Bogor.

https://pdfs.semanticscholar.org/536d/ecffc4d606 c7130cf050ea1bb9f8741543b4.pdf?_ga=2.15417 8040.1379570584.15825420911916090809.1553778741 .

Lailiyah, A., Susatyo, A. \& Dzakiy, M. A. (2016). Keanekaragaman Jenis dan Persebaran Mollusca di Pantai Bondo dan Pantai Prawean Bandengan Kebupaten Jepara. Bioma: Jurnal Ilmiah Biologi, 5(2), 1-11. doi: 10.26877/bioma.v5i2.2525

Litaay, M., Darusalam \& Priosambodo, D. (2014). Struktur Komunitas Bivalvia di Kawasan Mangrove Perairan Bontolebang Kabupaten Kepulauan Selayar Sulawesi Selatan. Paper presented at the Seminar Nasional MIPA, Bandung.

http://repository.unhas.ac.id/bitstream/handle/123 456789/11838/litaay\%20dkksemnas $\% 20$ mipa $\% 202014$.pdf?sequence $=1$.

Mardiani, M. (2014). Keanekaragaman Kelas Bivalvia di Pantai Ujung Pandaran Kecamatan Teluk Sampit Kabupaten Kotawaringin Timur. (Skripsi), Jurusan Tarbiyah Program Studi Tadris Biologi, 
Sekolah Tinggi Agama Islam Negeri Palangka Raya, Kalimantan Tengah.

https://adoc.tips/studi-keanekaragaman-kelasbivalvia-di-pantai-ujung-pandaran.html.

Marpaung, A. A. F. (2013). Keanekaragaman Makrozoobenthos Di Ekosistem Mangrove Silvofishery Dan Mangrove Alami Kawasan Ekowisata Pantai Boe Kecamatan Galesong Kabupaten Takalar. (Skripsi), Program Studi Ilmu Kelautan, Jurusan Ilmu Kelautan, Fakultas Ilmu Kelautan dan Perikanan, Universitas Hasanuddin, Makassar.

http://repository.unhas.ac.id/bitstream/handle/123 456789/6145/skripsi\%20anggi\%20azmita\%20f.\% 20marpaung.pdf? sequence $=1$.

Nurdin, J., Marusin, N., Asmara, A., Deswandi, R. \& Marzuki, J. (2006). Kepadatan Populasi dan Pertumbuhan Kerang Darah Anadara antiquata L.(bivalvia: Arcidae) di Teluk Sungai Pisang, Kota Padang, Sumatera Barat. Makara Journal of Science, 10(2), 96-104. doi: 10.7454/mss.v10i2.201

Patty, S. I. \& Rifai, H. (2013). Community Structure of Seagrass Meadows In Mantehage Island Waters, North Sulawesi. Jurnal Ilmiah Platax, 1(4), 177186.

Pratiwi, R. (2010). Asosiasi Krustasea Di Ekosistem Padang Lamun Perairan Teluk Lampung. Ilmu Kelautan Indonesian Journal of Marine Sciences, 15(2), 66-76. doi: 10.14710/ik.ijms.15.2.66-76

Rajab, A., Bahtiar \& Salwiyah. (2016). Studi Kepadatan dan Distribusi Kerang Lahubado (Glauconome sp) Di Perairan Teluk Staring Desa Ranooha Raya Kabupaten Konawe Selatan. Jurnal Manajemen Sumber Daya Perairan, 1(2), 103-114. http://ojs.uho.ac.id/index.php/jmsp/article/view/2 459.

Rappe, R. A. (2010). Struktur Komunitas Ikan Pada Padang Lamun Yang Berbeda Di Pulau Barrang Lompo. Jurnal ilmu dan teknologi kelautan tropis, 2(2), 62-73. doi: https://doi.org/10.29244/jitkt.v2i2

Rochmady. (2010). Rehabilitasi Ekosistem Padang Lamun. (Tesis), Program Pascasarjana, Universitas Hasanuddin, Makassar. http://aquaticcommons.org/23572/1/ssrnid3045214.pdf.
Rukanah, S. (2019). Keanekaragaman Kerang (Bivalvia) di Sepanjang Perairan Pantai Pancur Punduh Pidada Kabupaten Pesawaran. (Skripsi), Jurusan Pendidikan Biologi, Fakultas Tarbiyah dan Keguruan, Universitas Islam Negeri Raden Intan, Lampung.

http://repository.radenintan.ac.id/7276/1/skripsi\% 20 siti\%20rukanah.pdf.

Supratman, O., Sudiyar. \& Farhaby, A. M. (2019). Kepadatan dan Pola Sebaran Bivalvia pada Ekosistem Padang Lamun di Perairan Pulau Semujur, Kepulauan Bangka Belitung. Jurnal Biosains, 5(1), 14-22. doi: 10.24114/jbio.v5i1.11862

Susiana. (2011). Diversitas dan Kerapatan Mangrove, Gastropoda dan Bivalvia di Estuari Perancak, Bali. (Skripsi), Program Studi Manajemen Suberdaya Perairan, Jurusan Perikanan, Fakultas Ilmu Kelautan Dan Perikanan, Universitas Hasanuddin, Makassar. http://repository.unhas.ac.id/bitstream/handle/123 456789/130/2011_susiana_121107001.pdf?sequen ce $=2$.

Wijayanti, H. M. (2007). Kajian Kualitas Perairan Di Pantai Kota Bandar Lampung Berdasarkan Komunitas Hewan Makrobenthos. (Tesis), Program Pascasarjana, Universitas Diponegoro, Semarang.

https://core.ac.uk/download/pdf/11717282.pdf.

Yuniarti, N. (2012). Keanekaragaman dan Distribusi Bivalvia dan Gastropoda (Moluska) di Pesisir Glayem Juntinyuat Indramayu Jawa Barat. (Skripsi), Departemen Biologi, Fakultas Matematika dan Ilmu Pengetahuan Alam, Institut Pertanian Bogor, Bogor. https://repository.ipb.ac.id/bitstream/handle/1234 $56789 / 58979 /$ g12nyu.pdf? sequence=1 \&isallowed $=\mathrm{y}$. 